Tyndale Bulletin 67.2 (2016) 317-320

\title{
THE CHRIST-STORY OF PHILIPPIANS 2:6-11 NARRATIVE SHAPE AND PARAENETIC PURPOSE IN PAUL'S LETTER TO PHILIPPI ${ }^{1}$
}

Richard J. Weymouth

(weymouth@ptee.org)

This thesis argues the case that Philippians 2:6-11 represents a Pauline prose narrative (and is not a pre-Pauline hymn), which may be called the Christ-story, and should therefore be interpreted as prose narrative in terms of its form, function, and content; and that doing this provides fresh insights into a much studied and debated passage, some of which have hitherto remained unnoticed (or at least unreported), while providing a framework that now allows some previous major contributions to the study of this passage to be brought together in order to form a comprehensive overall interpretation.

The thesis is arranged in four parts: Part I first introduces the passage of Philippians 2:6-11, noting the vast amount of scholarship written about it, highlighting some important contributions of relevance, and outlining the plan of the study (Chapter 1), then introduces the letter to the Philippians itself, the basic situation of both Paul and his Philippian recipients and the occasion of the letter, including brief discussion of some critical issues, though focussing on the intersecting narratives of the epistle and, given that Philippi in the first century was a Roman colony with life dominated by Roman governance and values, on the letter's political background (Chapter 2).

Part II then deals with major lines of interpretation in the study of this passage, beginning with the issues of its literary form and authorship, whether Philippians 2:6-11 represents a pre-Pauline hymn or a Pauline narrative (Chapter 3); next attempting to specify the precise function of the passage within its epistolary context - whether

1 Richard J. Weymouth, 'The Christ-Story of Philippians 2:6-11: Narrative Shape and Paraenetic Purpose in Paul's Letter to Philippi' (PhD dissertation, University of Otago, Dunedin, New Zealand, 2015). Supervisors: Prof Paul Trebilco, Dr Colin Kruse. 
it is 'kerygmatic' or 'exemplary', or whether another more nuanced designation may be more appropriate, in particular by providing a detailed treatment of the paraenetic context of verses 6-11 and by strengthening M. Bockmuehl's case for a particular reading of the elliptical verse $5 \mathrm{~b}$, pointing additionally to a paradigmatic understanding of the passage in which participation is invited (Chapter 4); then, thirdly, seeking to identify the implicit stories within the explicit narrative, by focussing on the influential contribution of N. T. Wright on interpretation of the passage in light of his and R. W. Hoover's rendering of Philippians 2:6b, discussing its narrativetheological significance, and then asking what clues the text itself offers for identifying a particular narrative background against which it may be understood, particularly for its first hearers (Chapter 5).

Part III builds upon the conclusions of the previous chapters and begins to analyse and interpret the passage as a narrative, offering the major contribution of the thesis in two chapters. Initially, Chapter 6 explores previous attempts at defining a chiastic shape, regarded by the author as unsuccessful, before suggesting a more appropriate method to define the narrative shape of the passage, and explaining in detail how the passage works in terms of its narrative syntax, sentence structure and function. Then, Chapter 7 focuses on the narrative shape of Philippians 2:6-11, identifying its overall shape, and positing of it a modified narrative chiasmus, so structured as a consequence of Paul carefully narrating a series of reversals in his account of the story of Christ. The particular narrative reversals are discussed and justified in some detail, followed by an examination of two important narrative threads running through the entire story, with the chapter going on to provide a detailed literary analysis of the passage, exploring the narrative setting, characters, stage and function of each element in the text, and seeking to integrate interpretative decisions made earlier in the study.

Part IV, in final conclusion, offers a brief summary of the work, describing the main results demonstrated concerning the form, function and meaning of Philippians 2:6-11 in its epistolary context, and considering the power of the story as a shaper of other stories and in inviting participation in it (Chapter 8).

More specifically, the investigation, in supporting the overall thesis mentioned above, presents a case for each of the following conclusions: 
(i) that Philippians 2:6-11 should no longer be regarded as an early Christian hymn incorporated by Paul in his letter to the Philippians, but instead is best understood as two sentences of prose narrative, written by the apostle himself, and which may better be described as the 'Christ-story';

(ii) that the story of Philippians 2:6-11 should be interpreted as an exemplary-paradigmatic Pauline narrative, that is, with a dual epistolary function: as an exemplary story, it models the mindset in thought and action that Paul desires to be reproduced in the lives of his status-obsessed hearers, thus supporting the surrounding paraenesis in the epistle; and as a paradigmatic narrative it both functions to structure Christian existence in various ways and also invites participation in Christ, so that his story might begin to shape their own lives, from their situation at the time of writing, and until the last day;

(iii) that the Christ-story also implicitly relates a counter-imperial narrative, with implicit contrasts to the emperor and other ancient rulers, in which Paul implicitly calls the Roman Philippians to supreme allegiance to Jesus Christ as Lord and to the new heavenly politeuma under his lordship, while also providing them with encouragement as a Christian community in Philippi to appear as lights in a hostile world, with hope for future vindication of the steadfastness and unity that Paul urges them to maintain in the face of such opposition;

(iv) that Paul has given the Christ-story a (modified ' $\mathrm{V}$ ') $\mathrm{V}$-shape, and has carefully crafted it in order to narrate several key reversals in the journey of Jesus Christ (up to now unreported as such), which has resulted in the creation of a modified narrative chiasmus, a chiasmus of narrative events, the elucidation of which helps us to understand better the passage as a whole;

(v) that two narrative threads also run through the passage as a whole, which may be described as the story of the visible cruciform God, and the motif of the obedient servant; the first relates the story of the invisible God made visible, representing Christ's identity, posture and praxis, leading to his death on the cross, and implicitly revealing the surprising character of God, while the second both exemplifies and implicitly commands obedient servanthood for the Philippian community, closely linking the passage to its preceding and following paraenetic context;

(vi) that as a narrative in both form and content, the Christ-story needs to be interpreted as a narrative, allowing a detailed literary 
appreciation of its shape, motifs, and construction to assist in determining its overall meaning and function for both its first and subsequent hearers and readers; further, having concluded this, a final extensive literary, narrative analysis is provided, which relates each element of the text to its meaning for, and likely impact upon, the first hearers, while integrating other previous interpretative decisions into the discussion;

(vii) finally, that the climax of the story as a whole is to be found not in the act of acclamation of Jesus Christ as Lord, but in the centre of the narrative, in the shocking reference to Jesus dying what was regarded as a slave's humiliating death on a Roman cross; this conclusion is related to the other narrative elements to convey the overall narrative impact of this climax for both original and subsequent recipients of the letter. 